\title{
Fiziksel İstismar mı Yoksa Mavi Sklera mı? Olgu Sunumu
}

\author{
Is it Physical Abuse or Blue Sclera? A Case Report \\ Bedir Korkmaz, Mustafa Selim Özkök, Füsun Çallak Kallem, Musa Dirlik, Ufuk Katkıcı \\ Adnan Menderes Üniversitesi Adli Tip Anabilim Dalı, Aydın
}

\section{Özet}

Çocuğa yönelik kötü muamele, önemli bir halk sağlığı ve sosyal refah sorunu olmaya devam etmektedir. Her yıl, çocukların yaklaşık \%4-16'sı fiziksel istismara maruz kalmakta ve dünyada her yıl istismar ve ihmal yüzünden 155.000 çocuk hayatını kaybetmektedir.

Klinisyenler genellikle çocuk istismarın belirtileri ile istismarı taklit eden cilt lezyonlarının ayırımına varmakta zorlanmaktadırlar. Bu iki durumun ayırıcı tanısında dermatologlardan konsültasyon istenilebilir. Çünkü cilt hasarı istismarın en yaygın ve tanınan formudur.

Bu çalışmada, hastane kayıtlarına göre, babası tarafından fiziksel istismara uğradığı belirtilerek, yüzünde ve vücudundaki bulguların konjenital mi, yoksa fiziksel istismar sonrası mı oluştuğunun değerlendirilmesi için kliniğimize gönderilen 7 yaşında kız çocuk olgu sunulmuştur. Olgu, çocuk hastalıkları, dermatoloji ve göz hastalıkları bölümlerine konsülte edilmiştir. Görmesinin normal olduğu, retinal hasar bulunmadığı belirtilmiş, mavi sklera (retinanın incelmesi) tespit edilmiştir. Olgunun yüz ve vücudu porto şarabı lekesi bulguları ile uyumlu bulunmuştur. Yüz ve vücudundaki bulguların fiziksel istismar ile ilişkili olmadığı saptanmıştır. Bu çalışmada, fiziksel istismarın ayırıcı tanısında cilt hastalıkları bulguları değerlendirerek ve bazı metabolik hastalıkların göz önünde bulundurulması gerektiği vurgulanmıştır.

Anahtar kelimeler: Çocuk fiziksel istismarı; Mavi sklera; İstismarı taklit eden bulgular; Adli tıp.

\section{Giriş}

Çocuğa yönelik kötü muamele, önemli bir halk sağl1$\breve{g} 1$ ve sosyal refah sorunu olmaya devam etmektedir. Her yı1, çocukların yaklaşık \%4-16'sı fiziksel istismara maruz kalmakta ve dünyada her yıl istismar ve ihmal yüzünden 155.000 çocuk hayatını kaybetmektedir (1).

Fiziksel istismara uğramış çocuğa tanı konulamadığında, bu çocukların önemli bir kısmı tekrar istismara uğramakta ve hatta yaşamını yitirmektedir (2-5).

İstismar bulgularını tanımanın önemi ile birlikte ayırıcı tanısında bazı hastalıklar veya lezyonların iyi değer-

Sorumlu Yazar: Bedir Korkmaz

Adnan Menderes Üniversitesi Adli Tip Anabilim Dal, Aydın

E-posta: bedirkorkmaz@hotmail.com

${ }^{\star}$ Bu olgu sunumu 2015 yılında Isparta'da yapilan 12. Adli

Bilimler Kongresi'nde poster bildiri olarak sunulmuştur.

Geliş:18.08.2015 Düzeltme:12.10.2015 Kabul:13.10.2015

\begin{abstract}
Abuse of the children continues to be an important problem of public health and social welfare. Approximately $4-16 \%$ of all children are exposed to physical abuse and 155.000 children loose their lives due to abuse and neglect worldwide each year.

It is usually difficult to distinguish the skin diseases that mimics maltreatment and child abuse for clinicians. To distinguish between these two conditions a dermatologist may be consultated. Because skin damage is the most recognizable and common form of the abuse.

A seven years old girl who has been subjected to physical abuse by her father according to the hospital records and sent to our clinic for the evaluation of lesions on the face and body in terms of congenital or a sign of physical abuse was investigated in this study. Patient was consultated to pediatrics, dermatology and ophtalmology. It was found that the vision is normal, no retinal damage and blue sclera (thinning of the retina) was detected. The lesions on face and body were consistent with the porto wine stains. These findings on face and body were not associated with physical abuse. It is highlighted in this study that the lesions of skin disease and some metabolic diseases should be considered in the differential diagnosis of physical abuse.
\end{abstract}

Keywords: Child Physical Abuse; Blue Sclera; Mimickers of Physical Abuse; Forensic Medicine.

lendirilebilmesi gerekmektedir. Bu çalışmada, fiziksel istismar olarak yanlış değerlendirilen bulguların ayırıcı tanısında cilt, göz ve bazı metabolik hastalıkların göz önünde bulundurulması gerektiği vurgulanmıştır.

\section{Olgu}

Bu çalı̧̧mada, 7-8 aydır çocuk yurdunda kalan, ilköğretim ikinci sınıfa giden ancak okuma yazma bilmeyen, dört çocuklu bir ailenin üçüncü çocuğu olan 7 yaşındaki bir kız çocuk sunulmuştur.

Hastane kayıtlarına göre, babası tarafından muayene tarihinden 8 ay önce fiziksel istismara uğradığı belirtilmişti. Olgu, yüzünde ve vücudundaki bulguların konjenital mi, yoksa fiziksel istismar sonrası mı oluştuğunun değerlendirilmesi için kliniğimize gönderilmişti. Fizik muayenesinde: her iki yanakta, sol el sırtında, sol ön kolda, göğüste ve sırt sol tarafta yaygın etraf doku ile aynı 
seviyede, düzensiz sınırlı, kırmızı renkli hiperpigmente alanlar saptandı (Resim 1,2). Çocuk tarafından bu bulguların doğum lekesi olduğu ifade edildi. Sol gözde sklera üzerinde mavi renk değişikliği görüldü (Resim 3). Olgu, çocuk hastalıkları, çocuk psikiyatrisi, dermatoloji ve göz hastalıkları bölümlerine konsülte edildi. Görmesinin nor-

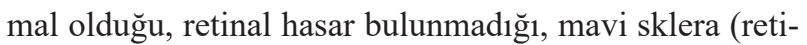
nanın incelmesi) tespit edildiği belirtildi.

Olgunun yüz ve vücut bölgesindeki hiperpigmente alanlar, porto şarabı lekesi (nevus flammeus) bulguları ile uyumlu idi. Laboratuvar tetkiklerinde hemoglobin 10.8 olduğu tespit edildi. Olgu, konjenital bir hastalığının olup

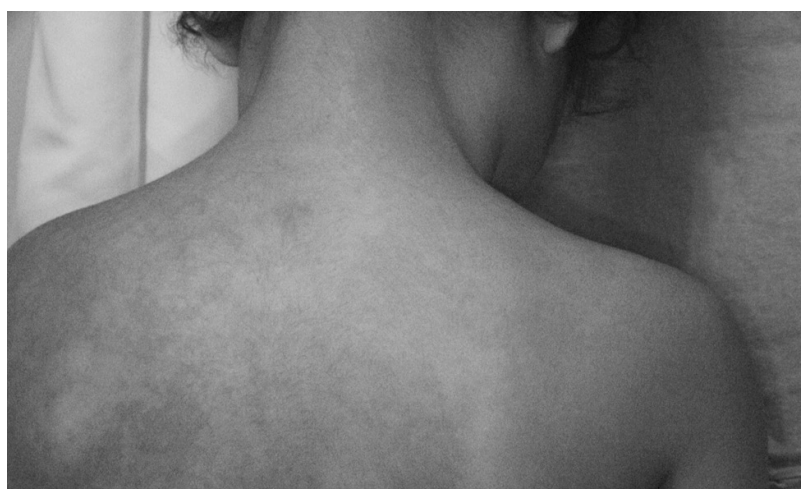

Resim 1. Sirtta sol tarafta daha yaygın etraf doku ile aynı seviyeli, düzensiz sınırlı, kırmızı renkli, hiperpigmente alanlar.

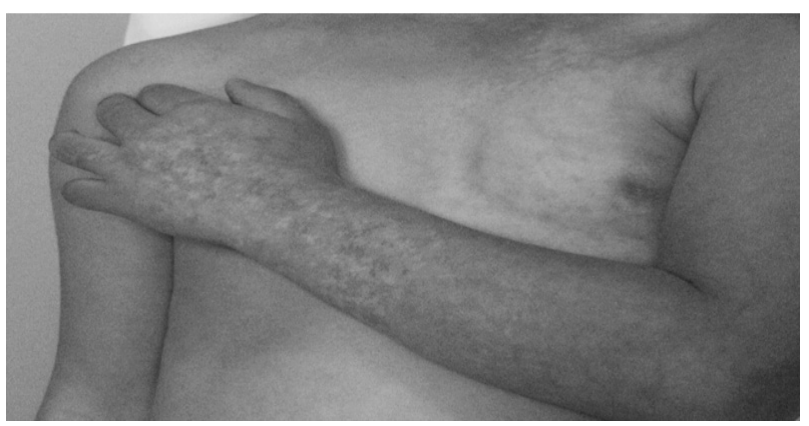

Resim 2. Sol el sırtı, sol ön kolda, göğüste sol tarafta daha yaygın etraf doku ile aynı seviyeli, düzensiz sınırlı, kırmızı renkli, hyperpigmente alanlar.



Resim 3. Sol gözde mavi sklera. olmadığ yönünden pediatri kliniği tarafindan takibe alınd1. Sitogenetik inceleme sonucunda 46XX olduğu, ancak bu değerlendirmenin submikroskobik kromozom aberasyonlarını, DNA'daki tek gen mutasyonlarını ve nadir mozaikleri ekarte etmeyeceği bilgilerine ulaşıldı. Sonuç olarak, bulguların fiziksel istismar ile ilişkili olmadığı şeklinde rapor düzenlendi.

\section{Tartışma}

Yedi yaşındaki olgu, dört çocuklu bir ailede yaşıyordu, birinci sınıfı bitirdiği halde okuma yazması yoktu ve ailesi düşük gelir düzeyine sahipti. Çocuğa yönelik kötü muamele risk faktörleri düşünüldüğünde, bu bilgiler çocuğun kötü muameleye uğrama ihtimalini arttırıyordu (6-8).

Olgunun, 8 ay önce babasının fiziksel istismarına maruz kaldığı belirtilmişti. İlk raporundan sonra gönderilen uzmanlarca mavi sklera ve kutenöz belirtilerin travma ile ilişkisi net olarak kurulamamıştı. Çocuğun önceden fiziksel istismara maruz kalması nedeniyle, mevcut bulgular ile istismar arasındaki bağlantıyı kurma noktasında uzmanlar ikileme düşmüştü. Bu nedenle olgu bölümümüze yönlendirilmişti.

Klinisyenler genellikle çocuk istismarın belirtileri ile istismarı taklit eden cilt lezyonlarının ayırımına varmakta zorlanmaktadırlar. Bu iki durumun ayırıcı tanısında dermatologlardan konsültasyon istenilebilir. Çünkü cilt hasarı istismarın en yaygın ve tanınan formudur (9).

Fiziksel istismarı taklit eden pek çok deri bulguları, genetik ve konjenital hastalıklar mevcuttur $(10,11)$. İstismar açısından yanlış tanı koymamak adına ayırıcı tanılar mutlaka dışlanmalıdır.

Olgumuzun yüzünde ve vücudunda yaygın kırmızı renkli hiperpigmente alanlar vardı. Dermatoloji konsültasyonunda bu alanların porto şarabı lekesi (nevus flammeus) bulguları ile uyumlu olduğu belirtilmişti. Olguda konjenital bir hastalık olan trigeminal sinirin oftalmik dağılımı üzerinde porto şarabı lekesi, beyin vasküler anormallikleri (leptomeningeal anjiom) ile karakterize ve potansiyel göz anomalilerini içeren Sturge Weber Sendromu (SWS) olup olmadığının değerlendirilmesi için çocuk hastalıkları konsültasyonu istenildi (12). Olgudan istenilen radyolojik tetkikleri yaptırmadığının belirlenmesi ve olgunun takibimizden çıkması nedeniyle kendisinde düşünülen SWS tanısı netleştirilemedi.

Olgumuzun sol gözünde sklerada mavi renk değişikliği vardı. Değerlendirilmesi için göz hastalıkları ve pediatri konsülasyonları istendi. Sitogenetik incelemeleri yapıldı. Laboratuvar tetkikinde hemoglobin 10.8 olduğu tespit edildi. Mavi skleranın osteogenezis imperfekta, demir eksikliği anemisi, Ehlers-Danlos sendromu, Hallermann-Streiff sendromu, hipofosfatasia, Lowe sendro- 
mu, Marfan sendromu, fenilketonuri, psödohipoparatiroidizm, psödoksantoma elastikum gibi pek çok nedeni olabilmektedir (13-15).

Olgumuzun hemoglobin değeri düşük olmasına karşın diğer hemogram değerleri normaldi. Demir eksikliği anemisi yoktu. Yapılan muayene ve yapılan testlerden elde edilebildiği kadarı ile genetik bir hastalık saptanmadı.

Çocuktaki bulguların fiziksel istismar ile ilişkili olmadığ 1 şeklinde rapor düzenlendi. Bu rapor düzenlendikten sonra çocuk bölümümüze bir daha gönderilmemesi ve takibimizden çıkması nedeniyle, kendisine net bir klinik tanı konulamadi.

İstismar bulgularını tanımanın önemi kadar ayırıcı tanısında bazı hastalıklar veya lezyonların iyi değerlendirilebilmesi gerekmektedir. İstismar tanısına multidisipliner yaklaşılması ve ihtiyaç duyulduğunda ilgili bölümlerden konsültasyon istenmesi gereken bir durumdur. $\mathrm{Bu}$ çalışmada, fiziksel istismar olarak yanlış değerlendirilen bulguların ayırıcı tanısında cilt, göz ve bazı metabolik hastalıkların göz önünde bulundurulması gerektiği vurgulanmıştır.

\section{Kaynaklar}

1. Pinheiro PS. World report on violence against children. New York:United Nations Secretary-General's study on violence against children, 2006.

2. Oral R, Blum KL, Johnson C. Fractures in young children: are physicians in the emergency department and orthope- dic clinics adequately screening for possible abuse? Pediatr Emerg Care 2003;19(3):148-53.

3. Leventhal JM, Thomas SA, Rosenfield NS, Markowitz RI. Fractures in young children. Distinguishing child abuse from unintentional injuries. Am J Dis Child 1993;147(1):87-92.

4. Jenny C, Hymel KP, Ritzen A, Reinert SE, Hay TC. Analysis of missed cases of abusive head trauma. JAMA 1999;281(7):621-26.

5. Oral R, Yagmur F, Nashelsky M, Turkmen M, Kirby P. Fatal abusive head trauma cases: consequence of medical staff missing milder forms of physical abuse. Pediatr Emerg Care 2008;24(12):816-21.

6. Hindley N, Ramchandani PG, Jones DP. Risk factors for recurrence of maltreatment: a systematic review. Arch Dis Child 2006;91(9):744-52.

7. Lee SJ, BellamyJL, Guterman NB. Fathers, physical child abuse and neglect. Child Maltreatment 2009;14(3):227-31.

8. Taner Y, Gökler B. Çocuk istismarı ve ihmali: psikiyatrik yönleri. Hacettepe Tıp Dergisi 2004;35:82-86.

9. Amy Swerdlin, Carol Berkowitz, Noah Craft. Cutaneous signs of child abuse. J Am Acad Dermatol 2007;57(3):371-92.

10. Oranje A, Bilo RA. Skin signs in child abuse and differential diagnosis. Minerva Pediatr 2011;63(4):319-25.

11. Wardinsky TD. Genetic and congenital defect conditions that mimic child abuse. J Fam Pract 1995;41(4):377-83.

12. Puttgen KB, Lin DD. Neurocutaneous vascular syndromes. Childs Nerv Syst 2010;26(10):1407 -15

13. Arı Ş, Haspolat K, Çaça İ. Metabolik kemik hastalıkları ve göz. Turkiye Klinikleri J Ophthalmol 2008;17(4):276-81.

14. Tunç B. Çocuklarda demir eksikliği anemisi. Türkiye Çocuk Hast Der 2008;2(2):43-47.

15. Tarım Ö. Göz ve endokrinoloji. Güncel Pediatri 2007;5:18-22. 